\title{
Study on Teaching Mode of Ship Management Courses Based on Teaching Informationization
}

\author{
Jia Fu \\ Tianjin maritime college \\ Tianjin China
}

\author{
Lian Jianxiu \\ Offshore Oil Engineering Co., Ltd. \\ Tianjin China
}

\begin{abstract}
The purpose of this paper is to promote the teaching of ship management course by using micro-classes. The method is to analyze the teaching information and development prospects, the convenience and practical features of the microclass design, the construction of teaching information by using the micro-class philosophy, analysis of the main knowledge and competency requirements the ship management course. The use of micro-class teaching to solve the problem of ship management course teaching, result is the actual teaching verification effective, which can be extended to other courses to provide reference. Innovation is to change the traditional classroom teaching, improve teaching effectiveness.
\end{abstract}

Keywords-Teaching information; Micro class; Ship management; Resource pool; Resource integration

\section{INTRODUCTION}

The core content of education information is teaching information. Teaching is the central work in the field of education. Teaching information is to make the teaching methods scientific and technological, the education information dissemination, the teaching method modernization. Education information requires the more comprehensive use of modern information technology based on computers, multimedia and Internet communications in education to promote education reform. Education information content is used for education and teaching process of various elements, its development and utilization is the core of education information, but also the key to the success or failure of education information.

In 2016, the ministry of education launched the "13th FiveYear Plan" for education information [1]. At present, new technologies such as cloud computing, big data, internet of things and mobile computing are gradually and widely used. The pace of informationization in all economic and social sectors is accelerating. The overall level of information in society deepening, the revolutionary impact of information technology on education has become increasingly evident. The internet plus action plan and the action plan for promoting the development of big data have been promulgated. The informatization has become a national strategy and the informatization of education is ushering in a major historic development opportunity. It is very important to actively promote the integration of information technology, education with innovation and development, complex teaching content, micro-class video and supporting resources in general the total capacity of dozens of Mega, the video format must be to support the network to play online streaming media grid, teachers and students can smooth online observation lesson, view lesson plans, courseware and other ancillary resources; but also can be flexible and convenient to download and save to laptops, mobile phones, MP4 And other terminal equipment to achieve mobile learning, selected teaching content generally require thematic prominent, pointing to a clear, relatively complete. Its teaching video clip as a whole teaching design, multimedia materials used in classroom teaching and courseware, teachers teaching reflection after class, students' feedback and textbooks of academic experts and other related teaching resources constitute a clear theme .Various types of compact theme unit resource pack, creating a real microteaching resources and environment micro-class resources with video teaching case characteristics. Host moderator, streaming media play, teaching time is shorter, less teaching content, highlighting a subject knowledge point or skill point, resource capacity is small, exquisite teaching design, classic demonstration cases, independent learning, easy to make practical, the advantages of supporting the related material ship, with the innovation of ship science and technology, the requirement for the comprehensive quality of seafarers is getting higher and higher. Based on the requirements of suitable posts, we should strengthen the knowledge and ability education and application capabilities, ensure operation level standards, and achieve the basic theoretical requirements of management level. To meet the needs and sufficiency of theory, the Ministry of education has a strong pertinence and applicability for the proportion of vocational education practice teaching and theoretical teaching, and ship management teaching is from content. It is particularly important to explore the new requirements of ship management. The main purpose of this paper is to explore the use of information-based teaching micro lesson mode to improve the teaching effect of ship management course.

\section{The MAIn CONTENT OF SHIP MANAGEMEnt COURSE}

The objective of the course ship management is to be familiar with the laws and regulations on the safety of marine transportation and the protection of the marine environment. It is not irregularities to ensure the safety of the ship's operation. Understand the ship structure and airworthiness control, and master the skills to ensure the ship's marine performance and ship safety. Mastering the safety operation and emergency handling methods and matters of attention of the ship, especially the safety of the marine engine, mastering the ability to respond to the ship's emergency. Understand marine safety supervision and ship safety management system, familiar with 
the requirements of ship personnel management, ship maintenance management, oil, material and spare parts management, etc. Meet the requirements of the relevant conventions for the management of the engine. We should clarify the resources and management concepts of the engine room, pay full attend to the role of the team of the engine department, reduce and eliminate potential human errors, ensure the safety of ship transportation at sea.

According to the requirements and contents of the course of ship management, the teaching design concept of ability as goal, project as carrier and teaching mode diversification" is introduced into the overall teaching design of this course. According to the requirements of the STCW convention, the regulation of the seafarers on duty in our country, and the competence of the three-pipe station, the teaching contents that the course contents are transformed into are expounded and the teaching methods suitable for the course are clarified

Ship management course is based on the people's republic of China ministry of communications maritime administration promulgated in 2016 the people's republic of China seafarers competency test program prepared to cover the latest IMO conventions and amendments and the latest marine laws and regulations [3]. ship anti-pollution management, ship operation safety management, ship safety emergency handling, ship repair and ship personnel management, as shown in Figure 1.

Modular project management of ship management knowledge, refinement project can be divided into hull force, the hull strength, the main hull structure and characteristics of the ship scale and ship factor, the ship's displacement, load and tonnage, ship load line, freeboard and back-up buoyancy, draft and Feet of Ships, concept of buoyancy of vessels, buoyancy of buoys, anti-heeling system of ships, stability classification of ships, stability of ships, anti-submergence of ships, international convention for the prevention of pollution caused by ships (MARPOL) regulations of the people's republic of China on the administration of the prevention and control of marine pollution by ships, regulations of the people's republic of China on the administration of the prevention and control of pollution of the marine environment by ships and their related activities, ship anti-pollution technology, constitution and major contents of international maritime safety and life convention, FSS rules, LSA rules, international safety management code (ISM Code), international safety management code Rules) certification, audit and supervision, international ships and The ISPS code, the international ship and port facility security code (ISPS Code) [2], the international ship weight line convention, the maritime traffic safety law of the people's republic of China, the maritime traffic accident investigation and handling regulations, people's republic of China ship safety operations and prevention of pollution management code, the ship registration certificate, ship classification certificate, the statutory certificate of the ship, the classification of ship inspection, class notation and additional signs, ship classification test .The types of ship inspection - to maintain class inspection, cycle inspection (CMS), mechanical inspection plan maintenance system (PMS), the statutory inspection of ships on international voyages, the main contents of the relevant equipment inspection of ships, the nature of the ship notary inspection, people's republic of China ship safety Inspection Rules, ship safety inspection and handling, "flag state supervision and inspection record book" and port state control Inspection report the use of provisions, port State control (PSC), the main PSC organization, port State control procedures, economic speed of the operating vessels, effect of speed on endurance, fuel consumption, emergency safety measures after the ship has been stranded, emergency safety measures, structure of the STCW convention on international standards for the training.

Certification and watch keeping of seafarers .The main contents and framework of the convention on maritime labor, the relevant provisions of the International health regulations and the labor law of the People's Republic of China, the relevant provisions of the regulations of the people's republic of China on seafarers, the customs and border control of the people's republic of China inspection agencies, frontier health and quarantine authorities on the management of the crew, the custody and use of the ship's materials, the management of the engine room and so on. Ship equipment maintenance, planning and repairs, the operation of the ship's inspection, ship energy conservation, ship pollution, its prevention and control of the environment, the ship safety department, crew management rules and regulations.

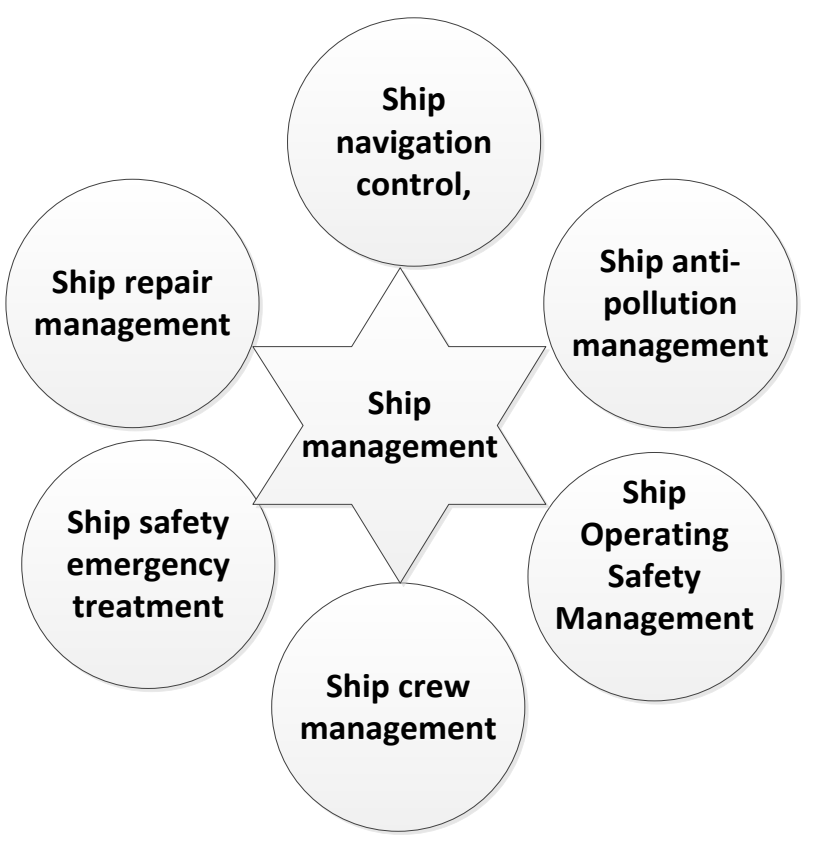

Fig. 1 Ship Management Structure 


\section{Ship Management Course Teaching Problems AND COUNTERMEASURES}

The safe and efficient operation of the ship must be completed by the crew. The operational safety and economic benefits of the ship are closely related to the professional qualifications and working efficiency of the crew. Therefore, only when the crew fully understands their responsibilities, in the duties they should undertake on board should they be clear about the job responsibilities of various departments so that they can exert their enthusiasm and creativity in an orderly and efficient manner. General classroom teaching more boring, students can not get a good grasp.

Micro-class can be related to the actual work of the ship relatively independent, the difficulty of moderate knowledge points made with a continuous screen 5-10 minutes of video, micro-class can create learning situations to make up for the lack of students lack of navigation experience and enhance student positions on board ,The actual perceptual knowledge of the work; enable students to study independently with the task to enhance students' motivation to learn and interest in learning; through the mobile terminal and other information tools give students a convenient and efficient self-learning conditions [3].

The use of micro-class teaching resources available to students self-study, students can video, case base, virtual simulation into the post work situation, to collect information, explore problems, establish learning content and practical work to stimulate students familiar with the work environment, clear Work tasks, confirm the work points.

With the help of micro class, the task statement, task training and assignments in class are simplified, and the utilization ratio and teaching effect are improved. At present, there are some problems in the teaching of ship management, such as emphasizing theory teaching and neglecting practice teaching.

Ship management is a combination of practicality and formativeness, which is indispensable and focuses on the combination of theory and practice [4], which is to standardize the practice teaching of students' behavior. However, some students are not active in learning and think that they have too much self-learning content [7].

They spend too much time and energy on information access and preparation before class, and their interest in teaching is not high. Some students encounter in self-regulated learning Do not understand the content, do not take the initiative to seek solutions, as time goes by, more and more accumulated problems, tired of school mood is also more serious [5], there are some students lack the necessary knowledge of the situation and role of practice in the learning process can not press Ship actual job role to complete the scene simulation. The creation of teaching situation must be based on the actual students, pay attention to its actual effectiveness. Each teaching situation should be designed for its pertinence. Generally speaking, teaching objectives should be put forward. The implementation of teaching activities and the evaluation and feedback of teaching effects should be completed. Finally, the intended learning objectives are achieved. Students' practical skills are cultivated at the same time Increased the relevant theoretical knowledge. In addition, taking into account the complex and variability of the classroom, the design of teaching situations should not be a fixed pattern, the entire teaching activities are a dynamic and changing situations, there should be room for students to play their own, which requires teachers have a solid teaching basic skills, rich experience in ship work and innovation ability to change There are still many teaching contents in daily course of ship management, such as the lack of teaching place needed to create some task situations, which affects the overall effect of teaching. In the new education background, daily teaching needs to seek development and innovation. For the above problems, the use of participatory teaching generally divided into two phases, one is pre-class preview [4], the second is the classroom discussion.

Because most of the school teaching time are fixed, if the class to join the discussion session, it is bound to take up the theoretical knowledge of the time to explain, but the knowledge of this course, although more scattered, but not difficult to understand that most students through self-study preview the main points of knowledge. Therefore, students are required to carry out self-study on the theoretical knowledge to be taught in this class before class, find out the key points of difficulty, specify the places they do not understand and the relevant knowledge that needs to be understood. Teachers no longer explain the theory of knowledge, but teachers and students ask each other questions, teachers grasp the situation of the students preview, students ask the teacher where they do not know and want to know the relevant knowledge. Finally, the teacher explained it in a unified way. This saves time for class discussions. Class discussion is also divided into two major sections, namely scenario simulation and case analysis. Scenario simulation is mainly to simulate certain scenes of the actual work on board in the classroom so as to let the students simulate the crew to participate in them and gain personal experience. The case analysis is mainly based on selected representative cases so that the students can analyze the reasons themselves and if it is what should be done to experience the same thing their own, and finally by the teacher to explain.

In the scenario simulation and case study teaching, we should rationally grasp the dominant role of teachers and students subjectivity, take students as the main body, and the leading role of teachers is to cultivate students' ability of active learning and learning to make their minds truly Move it.

Through group discussion, taking the stage to speak, etc, to activate the students' thinking, training adaptability, grasp the ability to control the overall situation, motivate students to obtain a successful emotional experience, so as to be psychologically satisfied, stimulate learning enthusiasm, so as to continuously improve student innovation Competence and overall quality.

Network interaction function of the online course teaching platform [8], the use of platform advance to the students push learning announcements and learning resources, guide students to login platform to complete autonomous learning, teachers keep track of students' self-learning situation, and from which a clear learning difficulties and students to be left to the classroom to solve focus. 


\section{CONCLUSION}

The development of teaching information and the ship management course should keep pace with the times. The application of micro-class to classroom teaching not only provides enough teaching resources for students to learn independently, but also ensures the updating of resources in the implementation of micro-class, including Use of electronic textbooks. Under such conditions, the micro-class introduced a large number of Internet technology, timely communication for teachers and students, to build an exchange platform, teaching management to achieve the micro-class and teaching content in line with the vocational education and teaching reform needs. The practice of ship management teaching proves that the introduction of micro-class mode, the student-centered teaching model can stimulate the enthusiasm of students and effectively solve the problem of students' concentration, supplement the classroom teaching with the micro-class form is effective and be welcomed by the students, improving classroom efficiency.

\section{ACKNOWLEDGMENT}

This work was financially supported by 2016 higher vocational and technical education research association of Tianjin, research on the effectiveness and evaluation of ship security consciousness and responsibility course based on cloud computing (Grant No. XVI130).

\section{REFERENCES}

[1] WANG Wan-bing, WANG Zhou-na.Application of Flip Class in Project Management of "Ship Management"[J]. Maritime Education Research, 2017,34 (02): 71-75. (In Chinese)

[2] Feng Zhide, Wang Yibing.Design-based "Ship Management" Curriculum Syllabus Design [J]. Maritime Education Research, 2016,33 (02): 49-52. (In Chinese)

[3] JIA Zai-ming.Application of Participatory Teaching in the Course of "Ship Management" [J]. Maritime Education Research, 2016,30 (02): 53-55. (In Chinese)

[4] CHENG Chun-xiang, CHEN Jin-song, YANG Zhi-yong.Research on "Ship Management" Teaching Reform Based on Online Open Curriculum [J]. Education Teaching Forum, 2017, (33): 88-91. (In Chinese)

[5] WANG Yi-bing, WANG Zhou-na, ZHENG Kai-yu. Project-based Instructional Design of "Ship Management" Course Based on Professional Activity Orientation [J]. Journal of Nautical Education, 2014, 31 (02): 46-48. (In Chinese)

[6] Peng Chen, Zhang Yuanyuan.A Strategy to Improve the Passing Rate of Ship Management (Marine) Under the 11 Rules"[J] .Journal of Wuhan Institute of Shipbuilding Technology, 2015,14 (06): 115-117. (In Chinese)

[7] JCHENG Chun-xiang, CHEN Jin-song, YANG Zhi-yong.Research on the Teaching Reform of "Ship Management" Based on Online Open Curriculum [J]. Education Teaching Forum, 2017, (33): 88-91. (In Chinese)

[8] Li Fuhai. Ship ManagementTeaching under the New Situation [J]. Journal of Qingdao Ocean Shipping Mariners College, 2013,34 (03): 57 59. (In Chinese) 